\title{
Simulasi Pergerakan Tumpahan Minyak di Laut dengan Pengaruh Angin
}

\author{
Nashrul Millah ${ }^{1}$, Indira Anggriani ${ }^{2}$, Kartika Nugraheni ${ }^{3}$ \\ ${ }^{1}$ Program Studi Matematika, Jurusan Matematika dan Teknologi Informasi, Institut Teknologi Kalimantan, \\ Balikpapan. Email: nashrulmillah@lecturer.itk.ac.id \\ ${ }^{2}$ Program Studi Matematika, Jurusan Matematika dan Teknologi Informasi, Institut Teknologi Kalimantan, \\ Balikpapan. Email: indira@lecturer.itk.ac.id \\ ${ }^{3}$ Program Studi Matematika, Jurusan Matematika dan Teknologi Informasi, Institut Teknologi Kalimantan, \\ Balikpapan. Email: kartikanheni@lecturer.itk.ac.id
}

\begin{abstract}
As a petroleum-producing country, Indonesia has a very important role in supplying national and international petroleum needs. The distribution of oil by sea raises the risk of spills and harms the marine environment, especially for marine life. Most oil spills in the marine environment can form a thin layer on the surface due to the movement of wind, waves, and currents. In this study, the oil spill movement model used the Shallow Water Equation (SWE) model and the equation for the movement of oil spills. The SWE model consists of the equation of mass and momentum derived from the law of conservation of mass which is derived into the equation of continuity and the law of conservation of momentum which is derived into the equation of conservation of momentum. In this model, ocean currents are affected by several disturbances in the form of wind gusts and friction with the bottom. The model is numerically solved through simulation using the finite volume method. Discretization is done by using a staggered grid approach, where the mass and momentum variables are discretized in different cells. From the simulation results, it appears that the movement of oil spills is influenced by wind direction and current. The simulation results also found that the speed of the movement of oil spills has increased in the early times, but then gradually become constant.
\end{abstract}

Keywords: numerical simulations, staggered grids, oil spills

\begin{abstract}
Abstrak
Sebagai negara penghasil minyak bumi, Indonesia memiliki peranan yang sangat penting dalam penyediaan kebutuhan minyak bumi nasional maupun internasional. Hal ini mendorong dilakukannya berbagai aktifitas pendistribusian minyak melalui jalur darat, udara, maupun laut. Distribusi minyak dengan jalur laut memunculkan resiko terjadinya tumpahan. Kejadian ini memberikan dampak buruk terhadap lingkungan laut, terutama bagi biota laut. Sebagian besar tumpahan minyak di lingkungan laut dapat membentuk sebuah lapisan tipis di permukaan akibat pergerakan angin, gelombang dan arus. Pada penelitian ini, model yang digunakan meliputi model Shallow Water Equation ( SWE) dan persamaan bagi pergerakan tumpahan minyak. Model SWE terdiri dari persamaan massa dan momentum yang didapat dari hukum konservasi massa yang diturunkan menjadi persamaan kontinuitas dan hukum konservasi momentum yang diturunkan menjadi persamaan kekekalan momentum. Model pergerakan tumpahan minyak mengikuti persamaan kontinuitas. Pada model ini, arus laut dipengaruhi oleh beberapa gangguan berupa hembusan angin dan gesekan dengan dasar. Model tersebut diselesaikan secara numerik melalui simulasi dengan menggunakan metode volume hingga. Diskritisasi dilakukan dengan pendekatan staggered grid dimana variabel massa dan momentum didiskritisasi pada sel yang berbeda. Dari hasil simulasi, terlihat bahwa pergerakan tumpahan minyak dipengaruhi oleh arah angin dan arus. Dari hasil simulasi juga didapat bahwa kecepatan gerak tumpahan minyak arah sumbu $x$ kian meningkat di waktu-waktu awal, namun kemudian berangsur konstan.
\end{abstract}

Kata Kunci: simulasi numerik, staggered grid, tumpahan minyak

\section{Pendahuluan}

Indonesia sebagai negara penghasil minyak bumi memiliki peranan yang sangat penting dalam penyediaan kebutuhan minyak bumi nasional maupun internasional. Hal ini mendorong dilakukannya berbagai aktifitas pendistribusian minyak ke daerah-daerah yang membutuhkan. Pendistribusian ini dilakukan baik melalui jalur darat, udara, maupun laut. Distribusi minyak dengan jalur laut 
memunculkan resiko terjadinya tumpahan minyak yang disebabkan karena kecelakaan kapal tanker, tumpahan minyak saat pengangkutan ke kapal, dan kebakaran kapal (Mukhtasor, 2007).

Koalisi Rakyat untuk Keadilan Perikanan (KIARA) mencatat sebanyak 37 kali kejadian tumpahan minyak di perairan Indonesia dalam rentang tahun 1998 sampai 2017. Kejadian ini memberikan dampak buruk terhadap lingkungan laut, terutama bagi biota laut. Pencemaran laut akibat tumpahan minyak juga akan mempengaruhi kehidupan masyarakat pesisir yang hidupnya bergantung pada laut. Lebih jauh lagi, penanganan yang tidak tepat akan memunculkan masalah baru seperti kebakaran yang tidak hanya mencemari laut tapi juga udara.

Balikpapan, sebagai salah satu pusat pengeboran minyak di Indonesia tidak lepas dari resiko terjadinya tumpahan minyak di laut. Pada tahun 2004, tumpahan minyak dari perusahaan Total E\&P Indonesia mengakibatkan nelayan tidak dapat melaut selama beberapa waktu (Hartanto, 2008). Kejadian ini terulang lagi pada tanggal 31 Maret 2018. Tumpahan minyak dari perusahaan Pertamina mencemari area perairan di teluk Balikpapan. Kejadian ini disebabkan oleh patahnya pipa Pertamina yang berada di kedalaman 20 meter dari permukaan laut.

Hasil pantauan Pusat Pemanfaatan Penginderaan Jauh Lembaga Penerbangan dan Antariksa Nasional (Pusfatja LAPAN) menunjukkan seminggu setelah kejadian tumpahan minyak menyebar seluas 12.987,2 hektar sebagaimana ditunjukkan pada Gambar 1. Kuatnya tekanan angin yang berhembus turut mempengaruhi pergerakan minyak yang berada di permukaan air laut. Penting untuk mengetahui bagaimana pergerakan tumpahan minyak di laut mengingat besarnya dampak pencemaran yang mungkin terjadi. Salah satu solusinya adalah dengan membuat model matematika pergerakan lapisan minyak di laut.

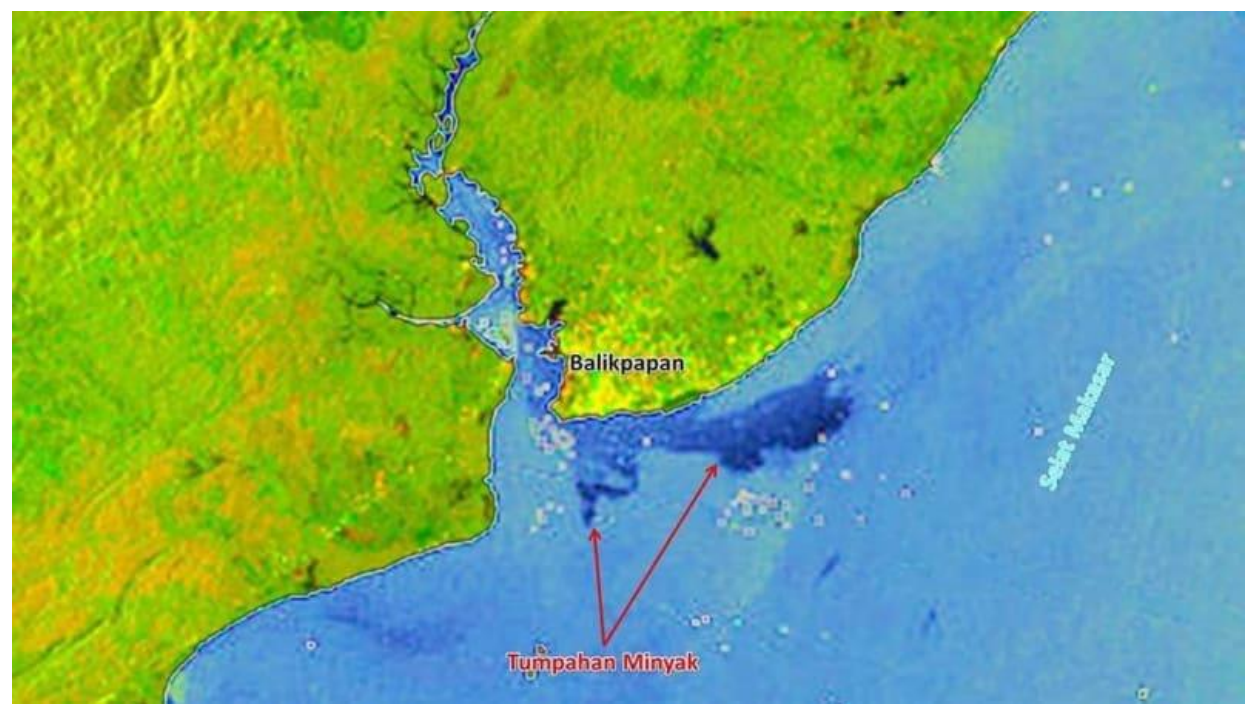

Gambar 1: Luas minyak yang tumpah di teluk Balikpapan

Penelitian mengenai pergerakan lapisan minyak ini pertama kali dilakukan oleh Fay $(1969,1971)$, Fannelop dan Waldmann (1971), Hoult (1972), dan Buckmaster (1973) dengan menganggap persebaran minyak sebagai pergerakan satu dimensi. Model yang dibuat mengambil asumsi tumpahan minyak terjadi pada air tenang, dimana tetesan minyak yang tumpah berbentuk lingkaran dan tidak mengalami perubahan bentuk, hanya perubahan diameter. Lebih jauh lagi, dikembangkan berbagai model untuk mensimulasikan pergerakan tumpahan minyak secara numerik (Tkalich, 2000, Aghajanloo dkk, 2013) dengan melibatkan sifat-sifat fisik dan kimiawi dari minyak (Stiver dan Mackay, 1984). Metode yang umum digunakan untuk mensimulasikan pergerakan tumpahan minyak adalah metode elemen hingga dengan pendekatan staggered grid (Zadeh, 2012, Aghajanloo dkk, 2013). 
Pada penelitian ini, akan dibuat model numerik untuk mensimulasikan pergerakan tumpahan minyak di laut. Pengaruh angin akan dipertimbangkan sebagai faktor yang mempengaruhi pergerakan lapisan minyak. Simulasi dilakukan dengan mengambil beberapa kasus dimana kekuatan angin yang bertiup berbeda-beda. Berdasarkan hasil simulasi bisa diketahui kecenderungan arah pergerakan tumpahan minyak sehingga proses pembersihan dapat diprioritaskan pada daerah dimana tumpahan minyak bergerak lebih cepat. Dengan demikian, diharapkan pencemaran laut akibat tumpahan minyak dapat diminimalisir. Kajian terhadap hasil simulasi program dapat diperoleh dalam kurun waktu lebih singkat dibanding dengan penelitian lapangan.

\section{Metode}

Metode yang digunakan pada penelitian ini meliputi pembentukan model matematika pergerakan tumpahan minyak di laut yang meliputi model Shallow Water Equation dan model pergerakan minyak. Model yang terbentuk diselesaikan secara numerik dengan metode Staggered Grid.

\subsection{Model Matematika Pergerakan Tumpahan Minyak di Laut}

Pada sub bab ini dijelaskan mengenai model persamaan matematika pergerakan tumpahan minyak di laut dengan penggabungan model Shallow Water Equation dan model persebaran minyak sebagai berikut.

\subsubsection{Model Shallow Water Equation}

Simulasi pergerakan tumpahan minyak dapat dibentuk menggunakan model persamaan air dangkal atau Shallow Water Equation (SWE). SWE adalah sistem hiperbolik dalam hukum konservasi yang menjelaskan tentang aliran geofisikal seperti sungai, area pesisir, lautan, atmosfir, dll (Swe-exner dan Hlle, 2018). Model SWE didapatkan dari integrasi hukum konservasi massa yang diturunkan menjadi persamaan kontinuitas dan hukum konservasi momentum yang diturunkan menjadi persamaan kekekalan momentum. Pada model ini, arus air laut dipengaruhi oleh suku difusi dan beberapa gangguan, yaitu hembusan angin dan gesekan dengan dasar. Berikut adalah model SWE yang digunakan pada penelitian ini (Kampf, 2009).

$$
\begin{aligned}
& \eta_{t}+\left(H u^{c}\right)_{x}+\left(H v^{c}\right)_{y}=0 \\
& u_{t}+u u_{x}+u v_{y}=-\frac{\tau_{x}^{b}}{\rho_{w}}+\frac{\tau_{x}^{w}}{\rho_{w}}+\frac{A_{h}}{H}\left\{\left(h u_{x}\right)_{x}+\left(h u_{y}\right)_{y}\right\} \\
& v_{t}+v u_{x}+v v_{y}=-\frac{\tau_{y}^{b}}{h \rho_{w}}+\frac{\tau_{y}^{w}}{h \rho_{w}}+\frac{A_{h}}{H}\left\{\left(h v_{x}\right)_{x}+\left(h v_{y}\right)_{y}\right\}
\end{aligned}
$$

$u(x, y, t)$ dan $v(x, y, t)$ merupakan vektor yang menyatakan kecepatan arus laut arah sumbu- $x$ dan sumbu- $y . h(x, y, t)=\eta(x, y, t)+d(x, y)$ merupakan kedalaman total air laut, $\eta(x, y, t)$ adalah elevasi air laut dan $d(x, y)$ adalah rata-rata kedalaman air laut. $\tau_{x}^{b}$ dan $\tau_{y}^{b}$ adalah gangguan dasar (bed friction), $\tau_{x}^{w}$ dan $\tau_{y}^{w}$ adalah tekanan angin (wind stress), dan $A_{h}$ merupakan viskositas air laut. Persamaan (1) menyatakan konservasi massa pada fluida tak mampat. Persamaan (2) dan (3) menyatakan konservasi momentum arah sumbu- $x$ dan sumbu- $y$.

Gangguan dasar pada model didefinisikan sebagai

$$
\begin{aligned}
& \tau_{x}^{w}=C_{f} u \sqrt{u^{2}+v^{2}} \\
& \tau_{y}^{w}=C_{f} v \sqrt{u^{2}+v^{2}}
\end{aligned}
$$

Dengan $C_{f}$ adalah konstanta (tak berdimensi) sebagai koefisisen gesekan. 


\subsubsection{Model Pergerakan Minyak}

Model persebaran tumpahan minyak dipengaruhi oleh kondisi cuaca dan kondisi lingkungan laut yang ada di sekitar tumpahan minyak. Minyak yang tumpah ke lingkungan perairan akan melalui beberapa proses fisis dan kimiawi, diantaranya dispersi, evaporasi, emulsifikasi, spreading, dan beaching. Perbedaan konsentrasi minyak dan air laut menyebabkan terjadinya proses difusi. Model persebaran minyak dapat dituliskan pada persamaan (4) berikut ini (Aghajanloo, dkk, 2009):

$H_{t}+H u_{x}^{o}+H v_{y}^{o}-\left(D H_{x}\right)_{x}-\left(D H_{y}\right)_{y}=R$

dengan $D=\frac{g H^{2}\left(\left(\rho_{w}-\rho_{0}\right) \rho_{0}\right)}{f \rho_{w}}$ adalah koefisien difusi, $g$ gravitasi, $H(x, y, t)$ ketebalan lapisan minyak, $\rho_{w}$ massa jenis air, $\rho_{o}$ massa jenis minyak, $f$ adalah gangguan interface air dan minyak. $u^{o}=u+$ $\tau_{x} / f, \tau_{x} \approx 0,03 u_{x}^{w}$ dan $v^{o}=v+\tau_{y} / f, \tau_{y} \approx 0,03 u_{y}^{w}$ adalah kecepatan minyak yang merupakan resultan dari kecepatan arus dan angin. $\tau_{x}$ dan $\tau_{y}$ adalah tegangan geser (shear stress) yang dipengaruhi oleh kecepatan angin $u_{x}^{w}$ dan $u_{y}^{w} . R$ adalah sifat fisis dan kimiawi yang mempengaruhi tumpah minyak. Pada model ini belum dimasukkan pengaruh sifat-sifat fisis dan kimiawi pada tumpahan minyak sehingga suku pada sisi kanan bernilai nol $(R=0)$.

\subsection{Metode Staggered Grid}

Ada dua cara yang bisa digunakan dalam proses diskritisasi suatu persamaan numerik, yaitu collocated grid dan staggered grid. Pada collocated grid, seluruh variabel didiskritisasi pada titik yang sama. Sedangkan pada staggered grid, variabel-variabelnya didiskritisasi pada titik yang berbeda. Variabel skalar, seperti tekanan, suhu, densitas, dan ketinggian didiskritisasi pada bagian tengah sel, sedangkan kecepatan atau variabel-variabel momentum didiskritisasi pada muka sel sebagaimana ditunjukkan pada Gambar 2. Variabel ketinggian $h$ didiskritisasi pada tengah sel, sedangkan variabel momentum $u$ dan $v$ didiskritisasi pada muka sel.

Metode staggered grid umumnya digunakan untuk diskritisasi persamaan pada simulasi aliran mampat (incompressible) dan tak mampat (compressible). Dengan menggunakan metode staggered grid dapat dilakukan diskritisasi dengan interval yang lebih kecil untuk menyelesaikan suatu turunan parsial.. Memperkecil interval pada diskritisasi harus diikuti dengan pengurangan time step untuk menjaga kestabilan solusi. Hal ini mengakibatkan waktu yang dibutuhkan untuk menjalankan program komputasi semakin panjang, begitu pula pengalokasian memori yang dibutuhkan lebih besar. Namun demikian, cara ini mampu menghasilkan solusi yang lebih realistis daripada diskritisasi collocated grid.

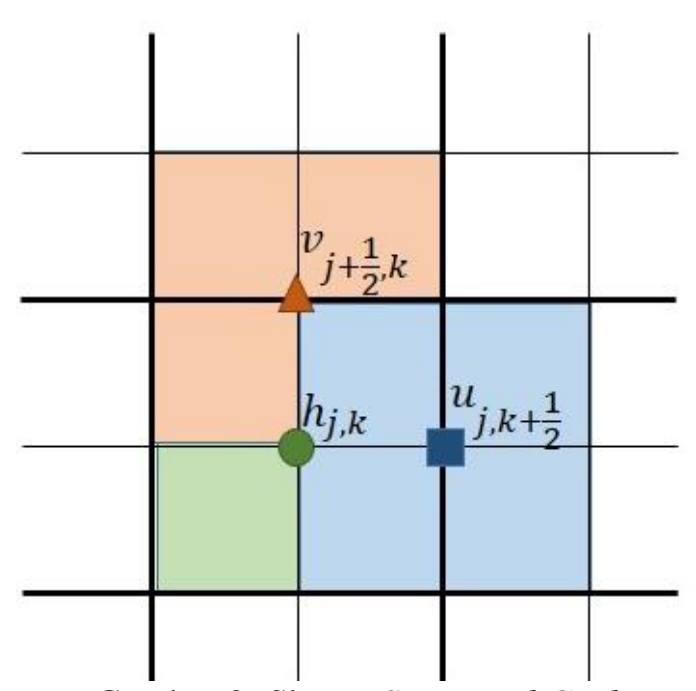

Gambar 2: Skema Staggered Grid 
Pada penelitian ini, diskritisasi dilakukan dengan menggunakan metode volume hingga pada staggered grid. Skema yang digunakan adalah center time center space atau yang dikenal dengan metode Leapfrog. Skema ini menghendaki perhitungan nilai di suatu titik melibatkan nilai pada titik sebelum dan sesudahnya. Ilustrasi metode Leapfrog ditunjukkan pada gambar 3.

Dengan mengaplikasikan skema leapfrog orde dua di sekitar $\left(x_{k}, y_{j}, t_{n}\right)$ untuk massa, di sekitar $\left(x_{k+\frac{1}{2}}, y_{j}, t_{n+\frac{1}{2}}\right)$ untuk momentum $x$, dan di sekitar $\left(x_{k}, y_{j+\frac{1}{2}}, t_{n+\frac{1}{2}}\right)$ untuk momentum $y$, diskritisasi komponen massa dan momentum diberikan oleh

$$
\begin{gathered}
\eta_{j, k}^{n+1}=\eta_{j, k}^{n}-\Delta t A d v_{\eta} \\
u_{j, k+\frac{1}{2}}^{n+1}=u_{j, k+\frac{1}{2}}^{n}-\Delta t\left(g \frac{\eta_{j, k+1}^{n+\frac{1}{2}}-\eta_{j, k}^{n+\frac{1}{2}}}{\Delta x}+A d v_{u}\right) \\
v_{j+\frac{1}{2}, k}^{n+1}=v_{j+\frac{1}{2}, k}^{n}-\Delta t\left(g \frac{\eta_{j+1, k}^{n+\frac{1}{2}}-\eta_{j, k}^{n+\frac{1}{2}}}{\Delta y}+A d v_{v}\right)
\end{gathered}
$$

sedangkan untuk persamaan ketebalan minyak diberikan oleh

$$
H_{j, k}^{n+1}=H_{j, k}^{n}-\Delta t A d v_{H}
$$

Suku $A d v$ merupakan suku non linier pada persamaan massa dan momentum. Dalam hal ini suku adveksi non linier diselesaikan dengan menggunakan skema Total Variation Diminishing (TVD) (Fringer, dkk, 2005) dimana nilai variabel dihitung menggunakan metode upwind.

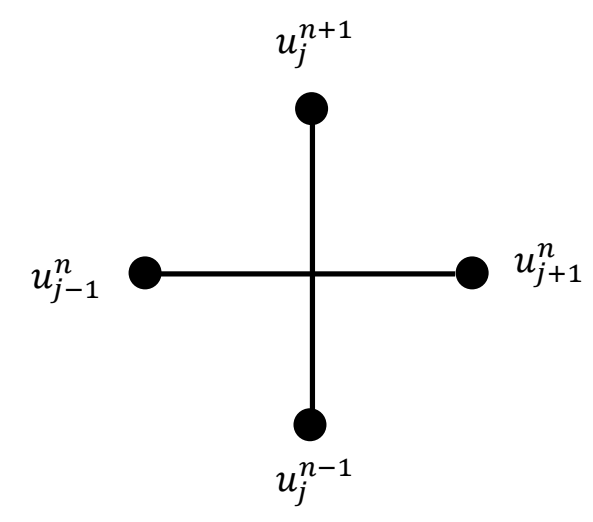

Gambar 3: Ilustrasi metode Leapfrog

\section{Hasil dan Pembahasan}

Simulasi dilakukan pada domain berukuran $120 \mathrm{~km}$ x $50 \mathrm{~km}$ dengan ukuran grid $(\Delta x, \Delta y)$ sebesar 100 m. Parameter yang digunakan pada simulasi ini yaitu gravitasi $(g)=9.81 \mathrm{~m} / \mathrm{s}^{2}$, koefisien gesekan dengan dasar $\left(C_{f}\right)=10^{3}$, massa jenis air $\left(\rho_{w}\right)=1028 \mathrm{~kg} / \mathrm{m}^{3}$, viskositas air $\left(A_{h}\right)=0.5 \mathrm{~m}^{2} / \mathrm{s}$, koefisien gangguan interface minyak-air $(f)=0.003$; massa jenis minyak $\left(\rho_{o}\right)=843 \mathrm{~kg} / \mathrm{m}^{3}$. Simulasi dilakukan untuk melihat pengaruh angin terhadap pergerakan tumpahan minyak. Simulasi diawali dengan meniupkan angin searah sumbu $x$ dengan kecepatan konstan $0.1 \mathrm{~m} / \mathrm{s}$. Pengamatan dilakukan selama 1 hari atau 24 jam. Hasil simulasi menunjukkan hembusan angin mempengaruhi arah arus air laut yang berakibat pada pergerakan tumpahan minyak. Gambar 4 menunjukkan pergerakan tumpahan minyak searah dengan hembusan angin dimana ketebalan minyak semakin berkurang dari waktu ke waktu. Setelah satu jam simulasi, posisi minyak berada pada jarak 11-19 km dengan ketebalan sekitar $16 \mathrm{~mm}$. 
Pada saat waktu 8 jam ketebalan minyak berkurang menjadi $10 \mathrm{~mm}$ pada jarak 37-46 km. Ketebalan tersebut terus berkurang pada waktu-waktu berikutnya.

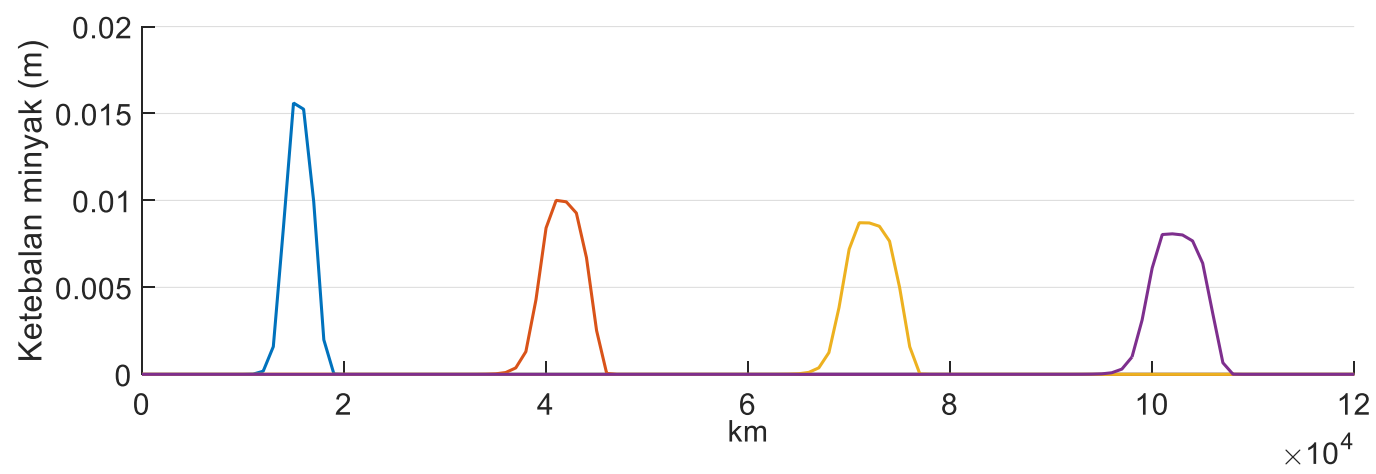

Gambar 4: Posisi dan Ketebalan minyak pada $t=1,8,16$, dan 24 jam dengan hembusan angin searah sumbu $x$

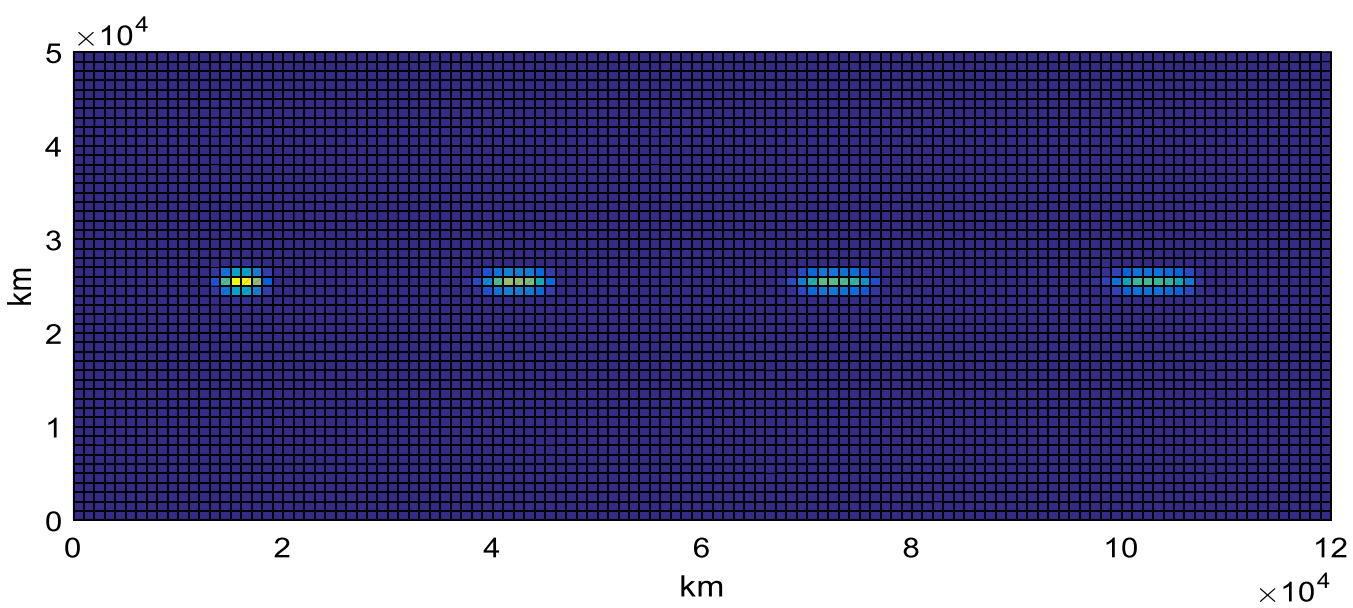

Gambar 5: Perubahan luas area tumpahan minyak pada $t=1,8,16$, dan 24 jam dengan hembusan angin searah sumbu $x$

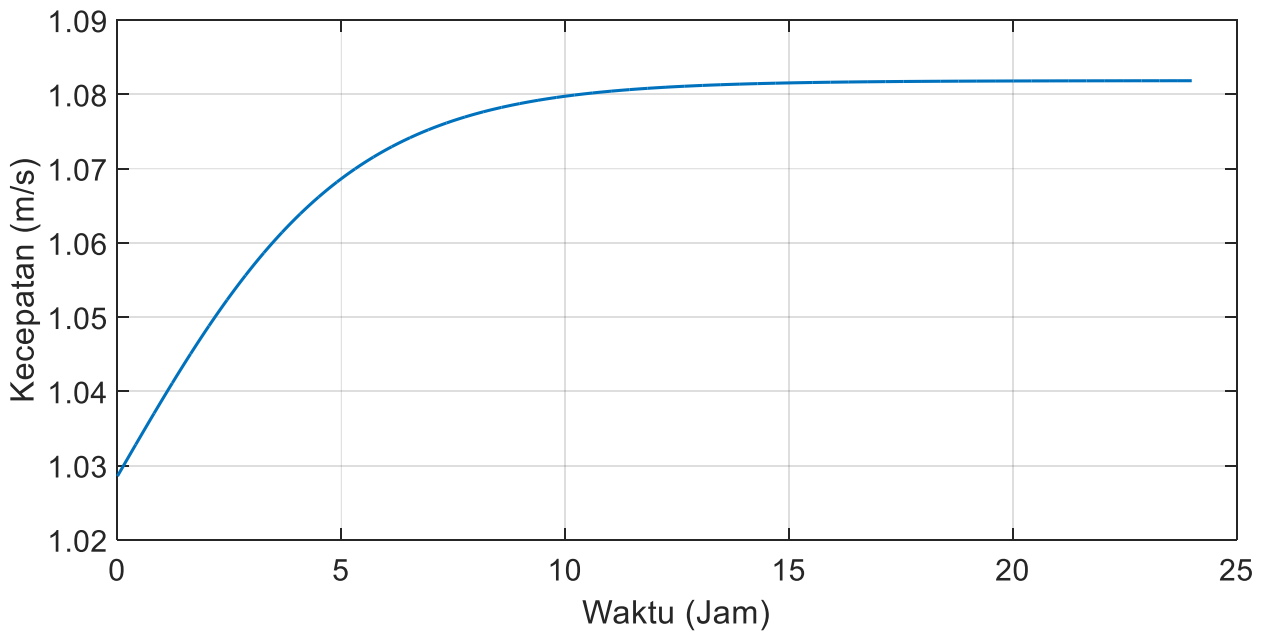

Gambar 6: Kecepatan pergerakan tumpahan minyak tiap waktu dengan hembusan angin searah sumbu

Berkurangnya ketebalan minyak disebabkan karena adanya proses penyebaran minyak yang merupakan akibat dari pergerakan arus laut yang dipengaruhi oleh hembusan angin. Gambar 5 menunjukkan perubahan luas area tumpahan minyak yang semakin membesar. Pada saat $t=1$ jam, 
luas area tumpahan minyak sekitar $14 \mathrm{~km}^{2}$, lalu melebar pada $t=8,16$, dan 24 berturut-turut sekitar $20 \mathrm{~km}^{2}, 23 \mathrm{~km}^{2}$, dan $25 \mathrm{~km}^{2}$. Perubahan luas area tumpahan minyak dipengaruhi oleh kecepatan angin, arah hembusan, kecepatan permukaan, dan jenis minyak. Pada simulasi ini, hembusan angin yang diberikan pada arah sumbu $x$ mengakibatkan kecenderungan area tumpahan meluas searah sumbu $x$. Sedangkan lebar luasan tumpahan pada arah sumbu $y$ relatif konstan.

Hasil simulasi juga menunjukkan adanya perubahan kecepatan pergerakan tumpahan minyak dari waktu ke waktu. Gambar 6 menunjukkan kecepatan pergerakan minyak pada arah sumbu $x$, sedangkan kecepatan arah sumbu $y$ bernilai $0 \mathrm{~m} / \mathrm{s} .10$ jam pertama, kecepatan pergerakan tumpahan minyak meningkat dengan cepat hingga mencapai $1,080 \mathrm{~m} / \mathrm{s}$. 14 jam berikutnya tumpahan minyak bergerak dengan kecepatan relatif konstan pada $1.081 \mathrm{~m} / \mathrm{s}$.

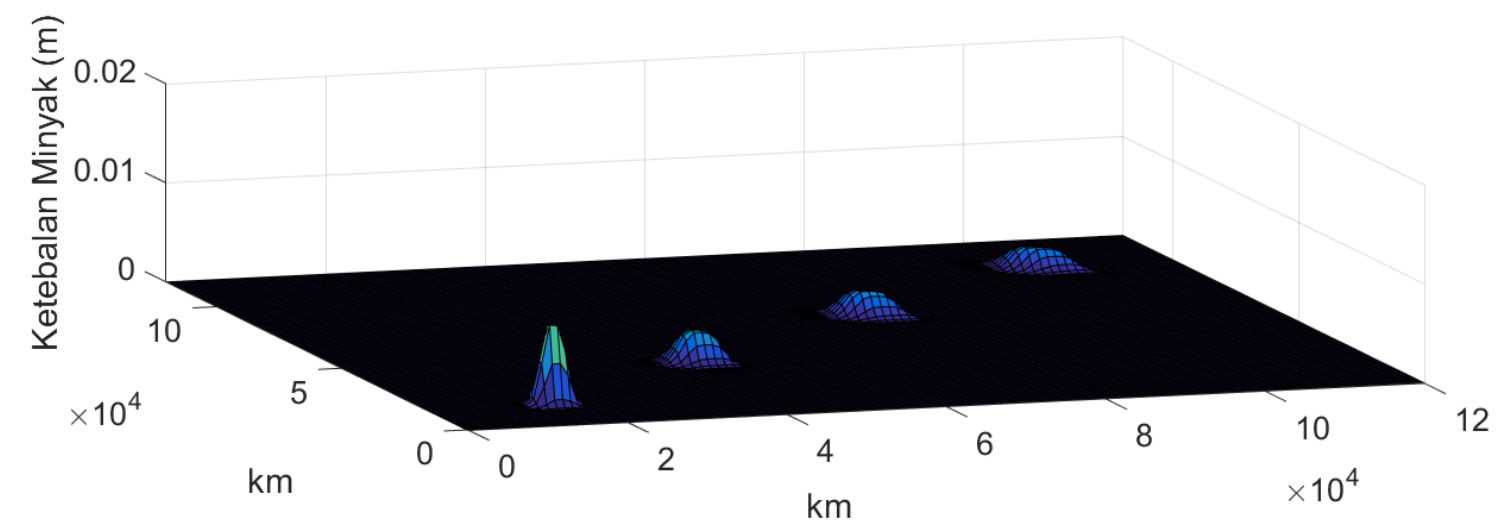

Gambar 7: Posisi tumpahan minyak pada $t=1,8,16$, dan 24 jam dengan hembusan angin searah sumbu $x$ dan $y$

Simulasi kedua dilakukan dengan meniupkan angin searah sumbu $x$ dan $y$, masing-masing sebesar 0,1 $\mathrm{m} / \mathrm{s}$. Dari hasil simulasi didapatkan bahwa tumpahan minyak bergerak pada arah diagonal seperti ditunjukkan pada Gambar 7. Ketebalan minyak berkurang lebih cepat hingga mencapai $0.0022 \mathrm{~m}$ pada $t=24$ jam. Hembusan angin dari dua arah tersebut juga mempengaruhi luas area tumpahan minyak. Berbeda dengan simulasi pertama, dimana luas area hanya melebar searah sumbu $x$, pada simulasi kedua luas area melebar ke segala arah seperti ditunjukkan pada Gambar 8. Kecepatan pergerakan tumpahan minyak pada arah sumbu $x$ dan $y$ ditunjukkan pada Gambar 9.

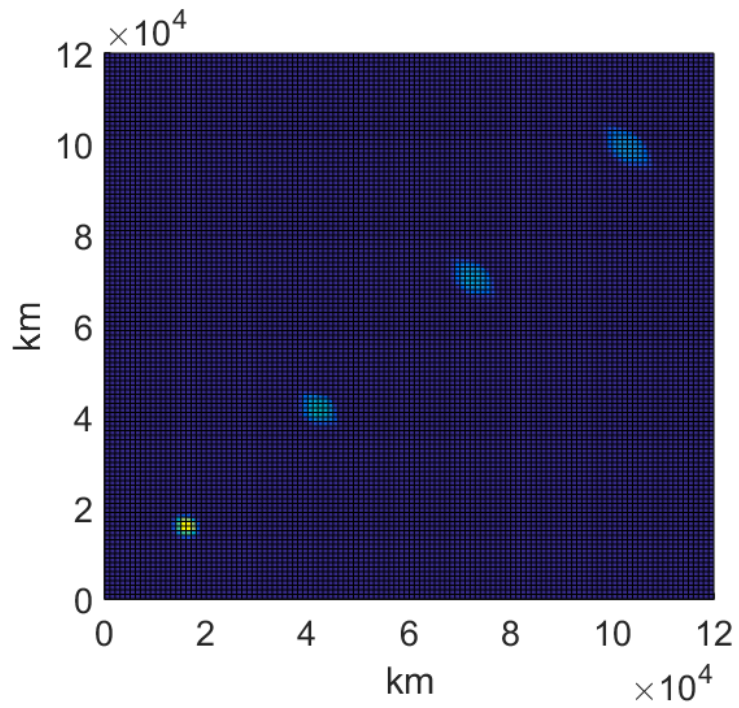

Gambar 8: Perubahan luas area tumpahan minyak pada $t=1,8$, 16, dan 24 jam dengan hembusan angin searah sumbu $x$ dan $y$ 


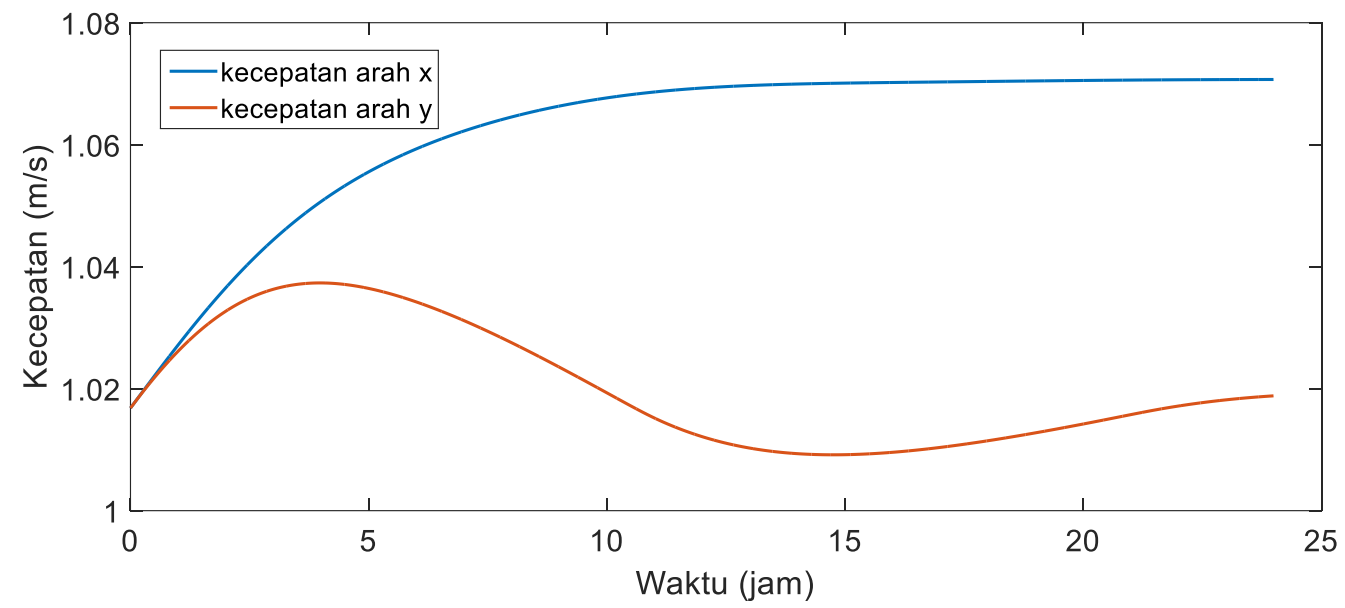

Gambar 9: Kecepatan pergerakan tumpahan minyak tiap waktu dengan hembusan angin searah sumbu $x$ dan $y$

\section{Kesimpulan}

Adapun hasil kesimpulan dari penelitian ini adalah sebagai berikut:

1. Pergerakan tumpahan minyak searah dengan hembusan angin dimana ketebalan minyak semakin berkurang dari waktu ke waktu. Ketebalan minyak berkurang disebabkan karena adanya proses penyebaran minyak yang merupakan akibat dari pergerakan arus laut yang dipengaruhi oleh hembusan angin.

2. Perubahan luas area tumpahan minyak yang semakin membesar dipengaruhi oleh kecepatan angin dan arah hembusan

3. Perubahan kecepatan pergerakan tumpahan minyak dari waktu ke waktu dipengaruhi oleh hembusan angin.

\section{Ucapan Terima Kasih}

Kami mengucapkan terima kasih kepada Kementerian Riset, Teknologi, dan Pendidikan Tinggi, yang telah memberikan dana hibah Penelitian Dosen Pemula (PDP), dan Lembaga Penelitian dan Pengabdian kepada Masyarakat Institut Teknologi Kalimantan (LPPM ITK) sehingga penelitian ini dapat dilaksanakan.

\section{Daftar Pustaka}

Aghajanloo,K, Pirooz, M. D, dan Namin, M.M. (2013). Numerical Simulation of Oil Spill Behavior in the Persian Gulf, International Journal Environmental Research, Vol. 7, No 1, Hal. 81-96

Buckmaster, J. (1973) .Viscous-Gravity Spreading of an Oil Slick., Journal of Fluid Mechanics, Vol. 59, No. 3, Hal. 481-491.

Fay, J. A. (1969) .The Spread of Oil Slicks on a Calm Sea., Oil on the Sea Plenum, New York, pp. 53 . 64.

Fay, J. A. (1971) .Physical Processes in the Spread of Oil on a Water Surface. Proceedings of the Joint Conference on Prevention and Control of Oil Spills, American Petroleum Institute, Washington D. C., Hal. 463-467

Fannelop, T. K, dan Waldman, G. D. (1971) .Dynamics of Oil Slicks., AIAA Journal, Vol. 10, No. 4, Hal.506510.

Fringer, O. B., Armfield, S.W., dan Street, R. L. (2005). Reducing Numerical Diffusion in Interfacial Grafity Wave Simulations., Int. J. Numer Methods Fluids, 49 (3), 301-329. 


\section{Simulasi Pergerakan Tumpahan Minyak di Laut dengan Pengaruh Angin}

Hartanto, B. (2008). Oil Spill (Tumpahan Minyak) di Laut dan Beberapa Kasus di Indonesia, Bahari Jogja. Vol. 8, No 12

Hoult, D. P.(1972). Oil Spreading on the Sea., Annual Review of Fluid Mechanics, Hal.341- 367.

Kampf, J. (2009). Ocean Modelling for Beginners Using Open-Source Software, London:Springer.

Mukhtasor. (2007). Pencemaran Pesisir dan Laut. PT Pradnya Paramita. Jakarta.

Pudjaprasetya, S. R. (2018). Transport Phenomena Equations and Numerical Methods. ITB Press. Bandung

Stiver, W. dan Mackay, D. (1984). Evaporation Rate of Spills of Hydrocarbons and Petroleum Mixtures. Environ. Sci. Technol, 18, Hal. 834-840.

Swe-exner, S., dan Hlle, F. (2018). Implementasi Skema Collocated, 3(March), 85-96.

Tkalich, P. (2000). Numerical Simulation of Oil Spills and Oil Combating Techniques, Oil and Hydrocarbon Spills II : Modelling, Analysis and Control. WIT Press

Zadeh, E. S. dan Hejati, K. (2012). Eulerian Oil Spills Model Using Finite-Volume Method with Moving Boundary and Wet-Dry Fronts., Modelling and Simulation in Engineering. Hindawi Publishing Corporation. 